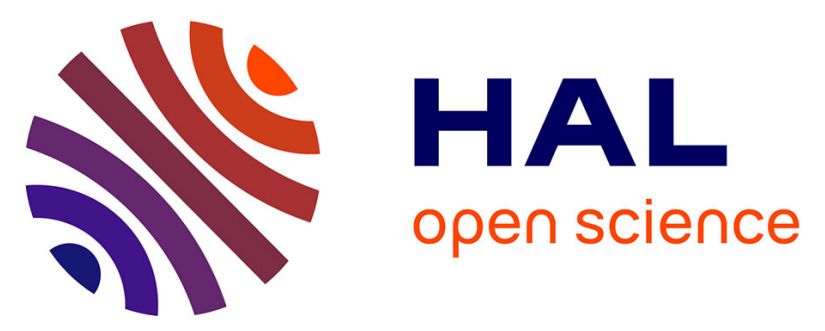

\title{
Lignocellulosic fiber reinforced composites: influence of compounding conditions on defibrization and mechanical properties
}

Johnny Beaugrand, Françoise Berzin

\section{- To cite this version: \\ Johnny Beaugrand, Françoise Berzin. Lignocellulosic fiber reinforced composites: influence of com- pounding conditions on defibrization and mechanical properties. Journal of Applied Polymer Science, 2013, 128 (2), pp.1227-1238. 10.1002/app.38468 . hal-01267981}

\section{HAL Id: hal-01267981 \\ https://hal.science/hal-01267981}

Submitted on 29 May 2020

HAL is a multi-disciplinary open access archive for the deposit and dissemination of scientific research documents, whether they are published or not. The documents may come from teaching and research institutions in France or abroad, or from public or private research centers.
L'archive ouverte pluridisciplinaire HAL, est destinée au dépôt et à la diffusion de documents scientifiques de niveau recherche, publiés ou non, émanant des établissements d'enseignement et de recherche français ou étrangers, des laboratoires publics ou privés. 


\section{Impact of thermo-hydro environment and specific mechanical energy on defibring using flow modelling and extrusion}

Johnny BEAUGRAND, Françoise BERZIN

INRA, FARE research unit, Reims, France

(Fractionation of lignocellulosic resources and Environment)

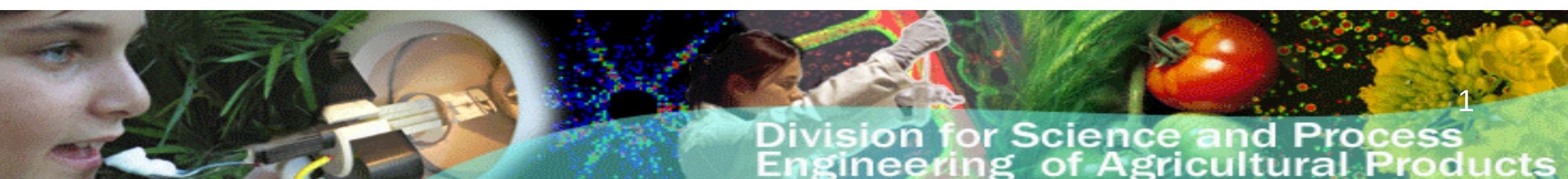




\section{Lignocelluloses defibring}

Aspect ratio ' $\mathrm{L} / \mathrm{W}$ '

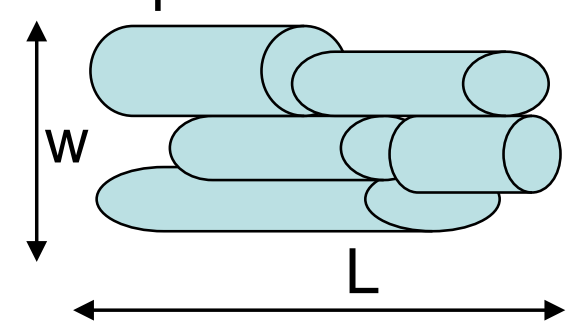

Lignocellulosic fibres

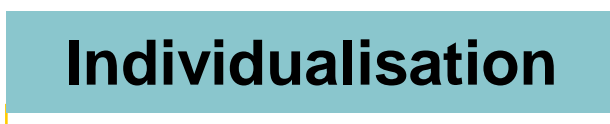

Extrusion

And Fragmentation

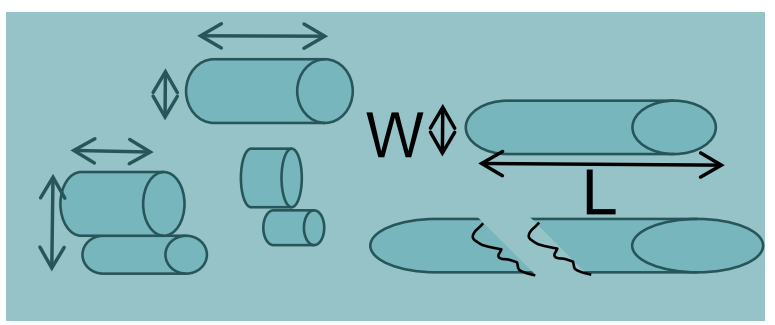

Compound/Composite material

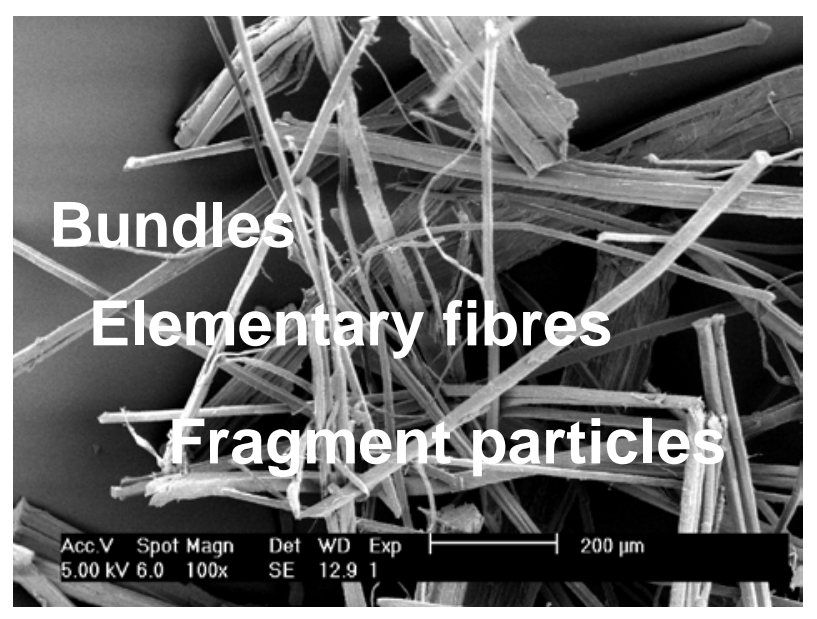

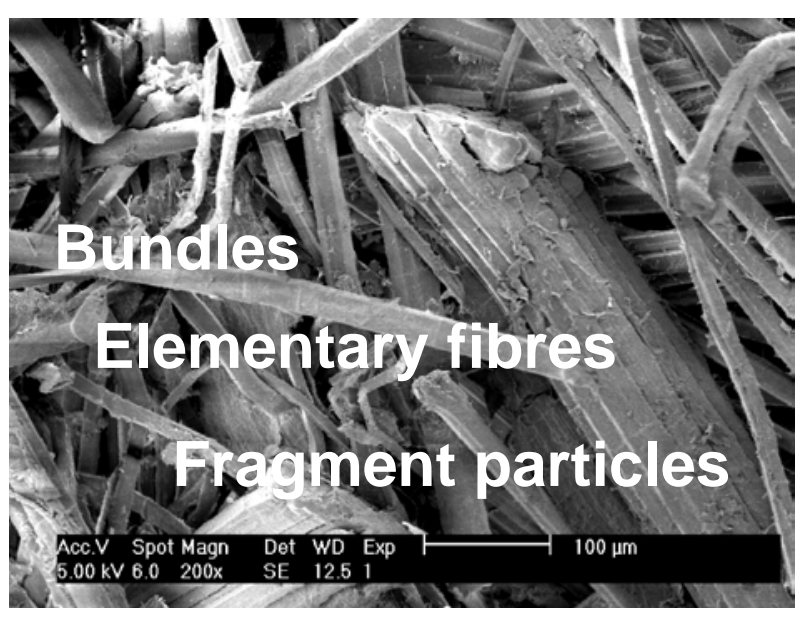

$\checkmark \Delta$ Distribution profile

We know: Aspect ratio 'L/W' and size influence composite end uses properties Is it possible to control the defibring in order to enhance the mechanical properties of composites? 


\section{Control of the defibring : hypothesis about fibre' ruptures}

\section{locations?}

Inter fibres (individualisation) Intra fibres (fragmentation)

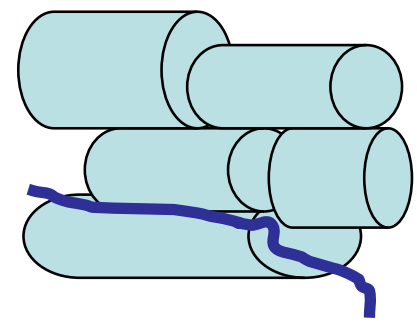

Structure

Theorical L/W

Theorical material reinforcement decohesion

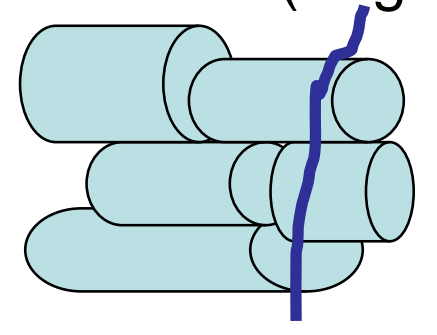

dammage

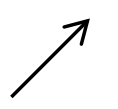

$\searrow$ or $\longrightarrow$

origins?

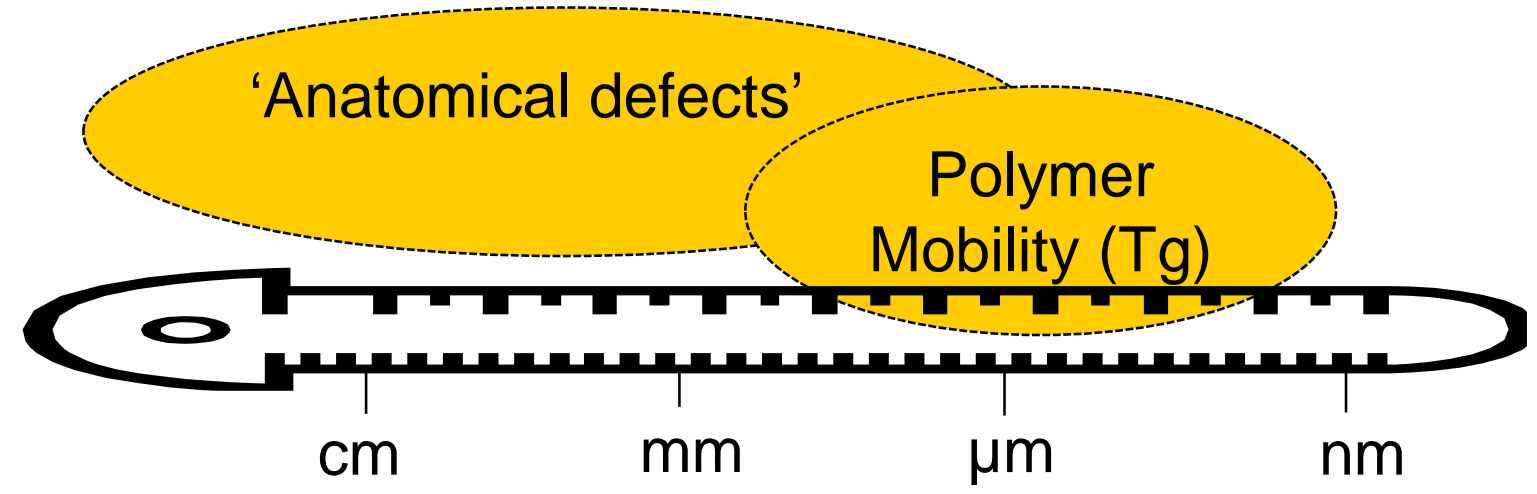




\section{First strategy : playing on fiber polymer mobility}

Spatial arrangement of Lignocellulosic polymers

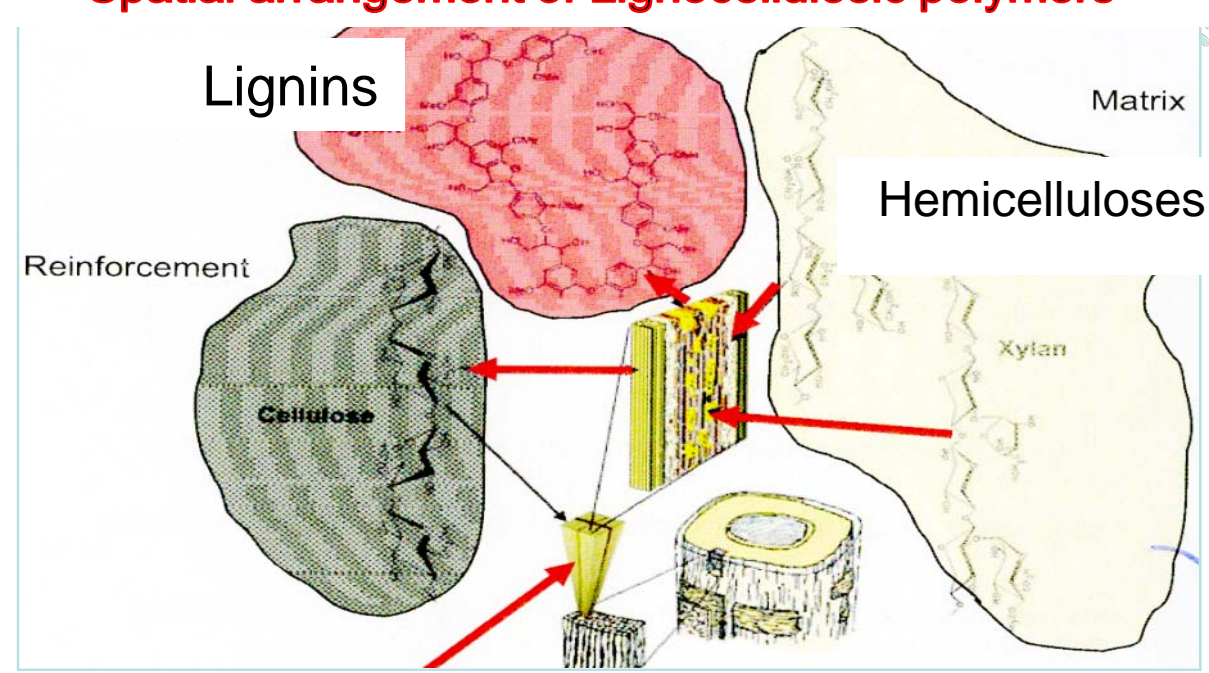

From Salmén and Olsson 1998

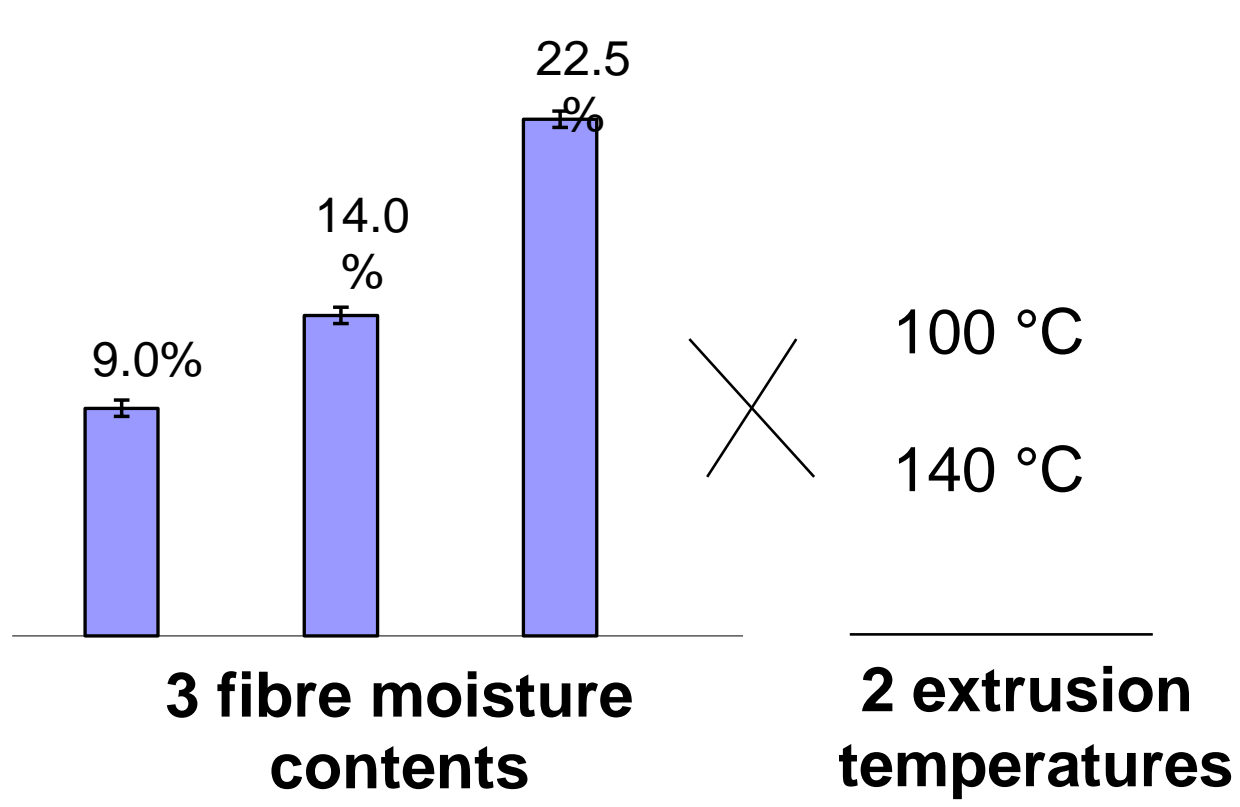

Macroscopic impact

$\downarrow$

Rupture location
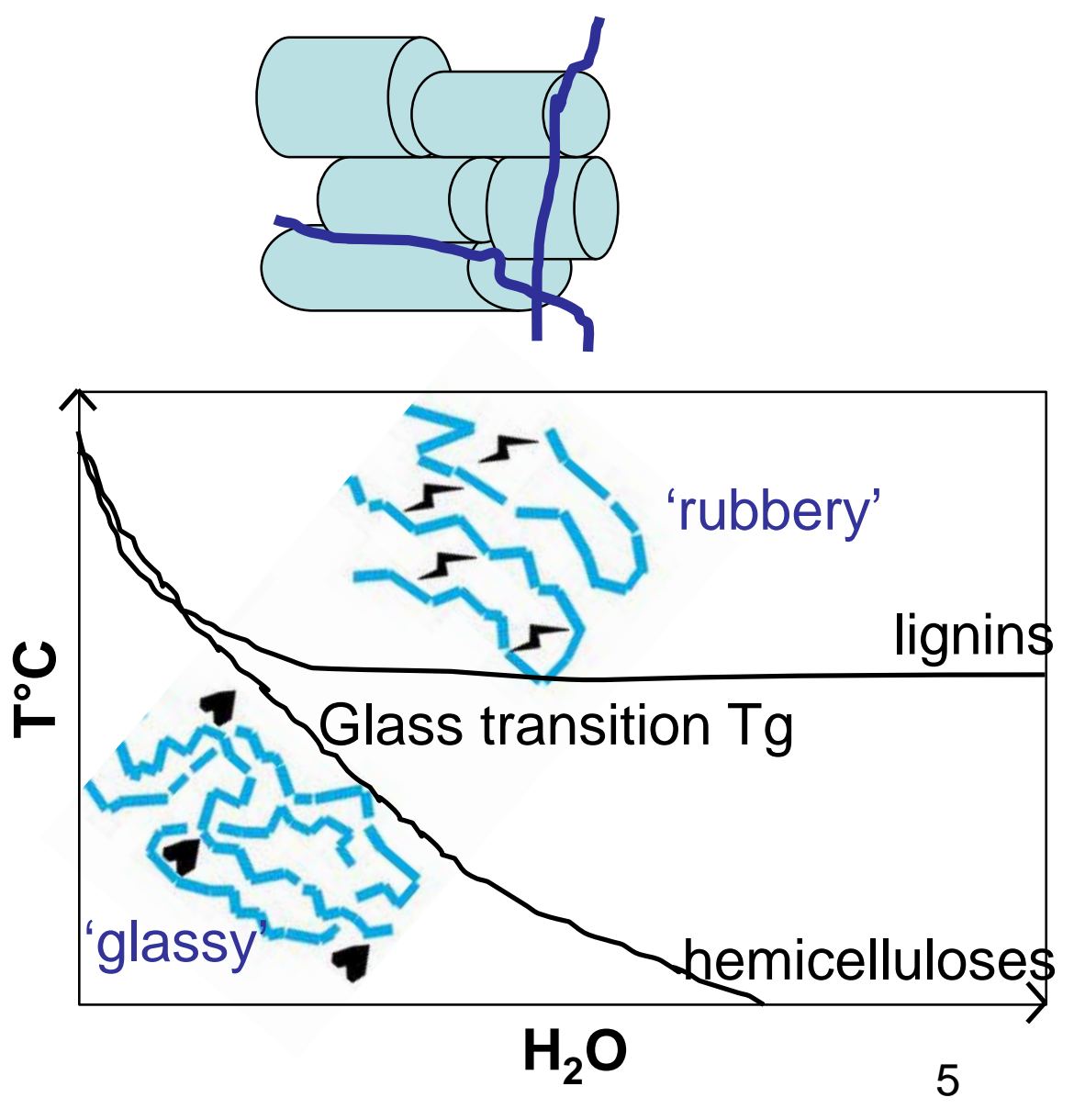


\section{Second strategy : playing on extrusion process}

\section{Taken from glass fibre}

SME Specific Mechanical Energy (kWh/t) intensity of the thermomechanical treatment

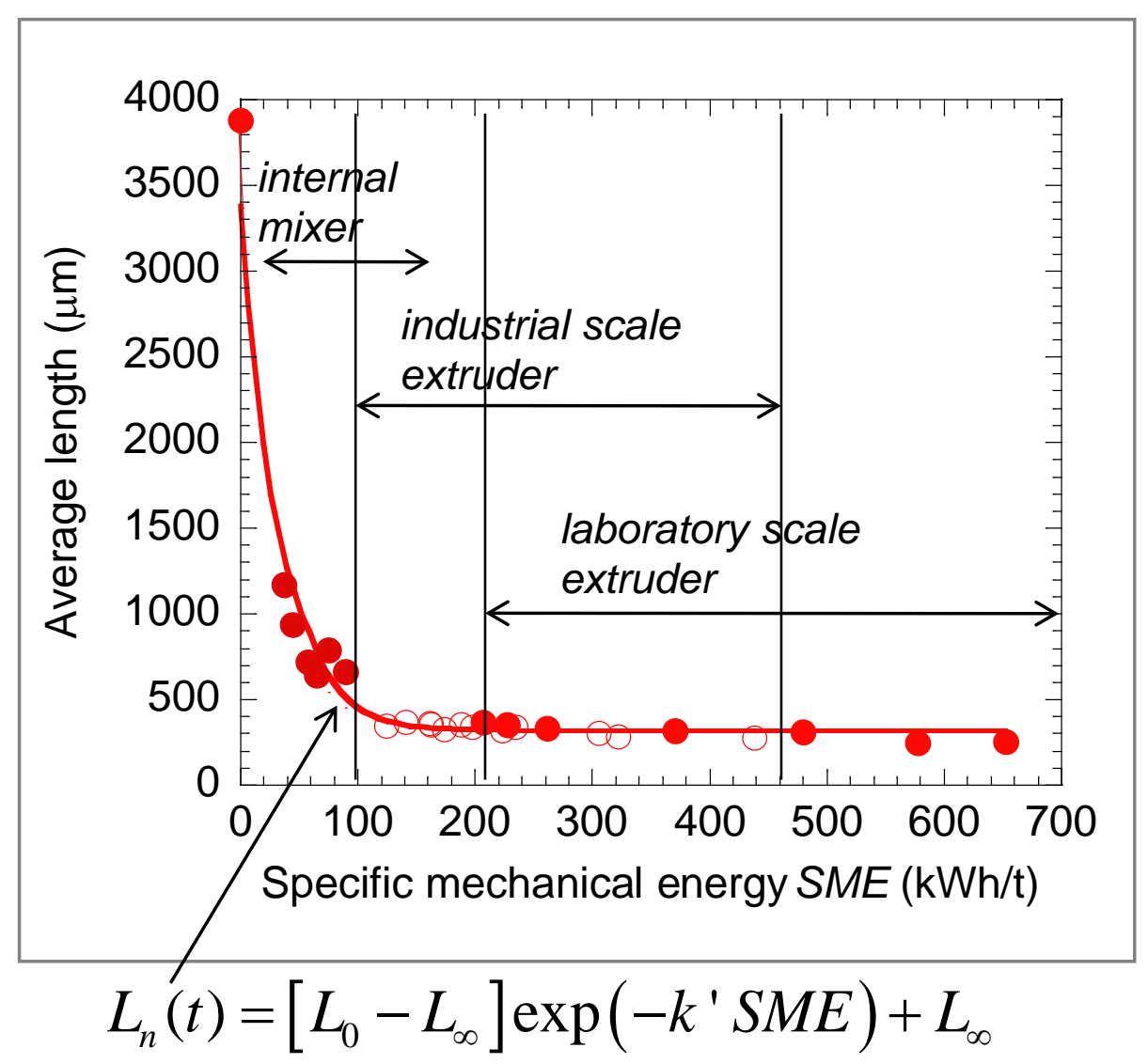

Transposable to natural fibres?

$$
S M E=\frac{1}{Q} \frac{N}{N_{\max }} r \frac{C}{C_{\max }} W
$$

Where:

$Q$ is the mass feed rate,

$N$ is the screw speed,

$N_{\max }$ the maximum screw speed (680 rpm),

$r$ the motor efficiency (0.93),

$C$ the torque,

$C_{\max }$ the maximum torque,

$W$ the nominal power $(9.2 \mathrm{~kW})$ 


\section{Materials and methods}

- Materials

$\varepsilon$-caprolactone $\rightarrow T_{\text {melting }}: 60^{\circ} \mathrm{C}-M_{w}: 80.000 \mathrm{~g} / \mathrm{mol}$

Hemp bast fibre $20 \%(w / v) \rightarrow 2 \mathrm{~cm}$ length on average

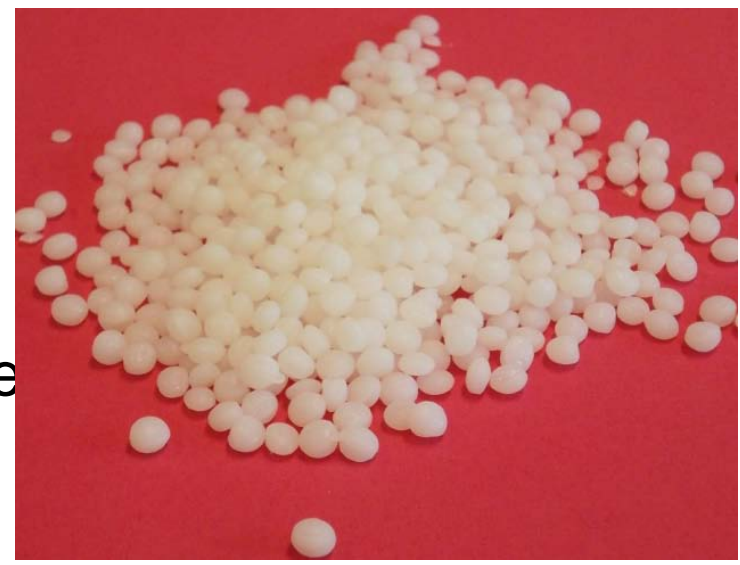

ㅁtrusion

Laboratory scale twin-screw extruder (Clextral BC 21)

$\square$ Trials

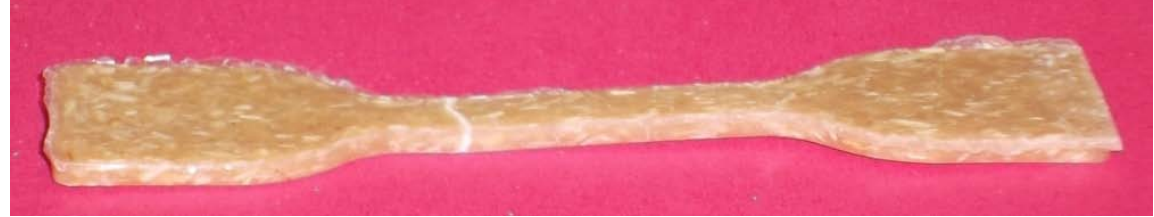

Compounding caprolactone / fibres in different conditions Analyze of fiber L/W in compounds Analyze of mechanical properties Young modulus and Yield $\mathrm{max}_{\max }$ (tensile tests)

- Simulation/modeling of the fibre' thermomechanical history 


\section{Twin-screw extrusion modeling software}

$\square$ LUDOVIC $^{\odot}$ : global model based on mass and thermal balance equations allowing to calculate the principal flow parameters

Vergnes et al., Polym. Eng. Sci., 1998 http://www.scconsultants.com

- Pressure

- Shear rate

- Temperature

- Residence time

- Filling ratio...

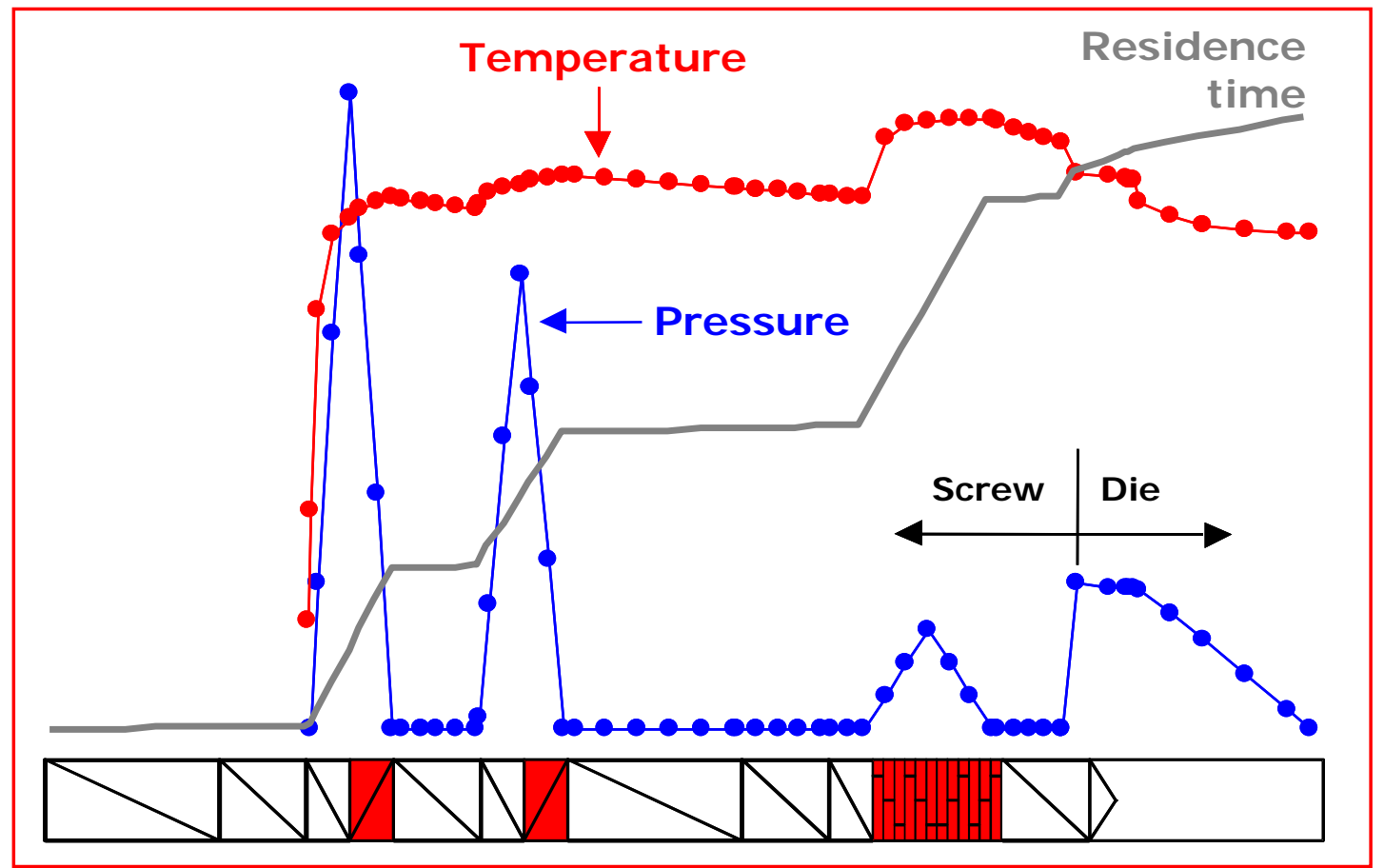




\section{Extrusions set up}

Screw

profile 1

'hard'

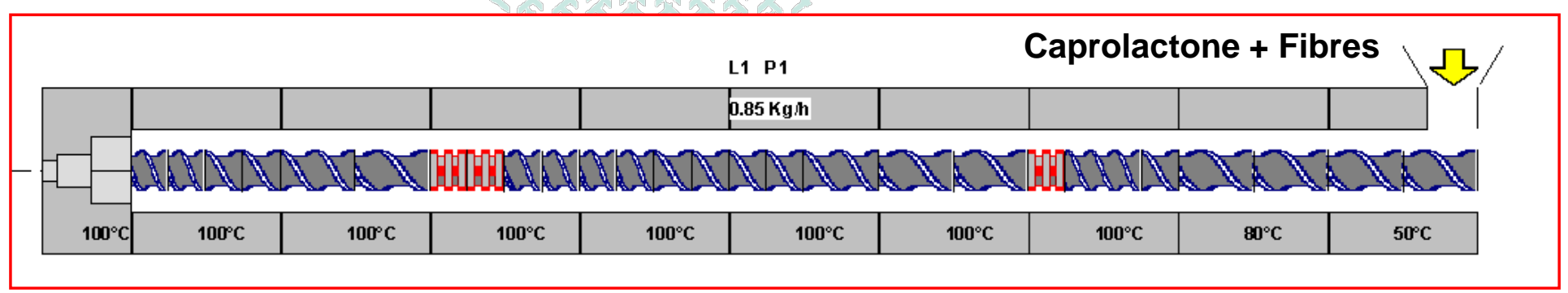

Study of formulation (at constant screw speed $250 \mathrm{rpm}$ and feed rate $0.85 \mathrm{~kg} / \mathrm{h}$ )

- Influence of fibre water content: $9-14-23(\%)$

- Influence of temperature: $100-140\left({ }^{\circ} \mathrm{C}\right)$

\section{Screw}

profile 2 'soft'

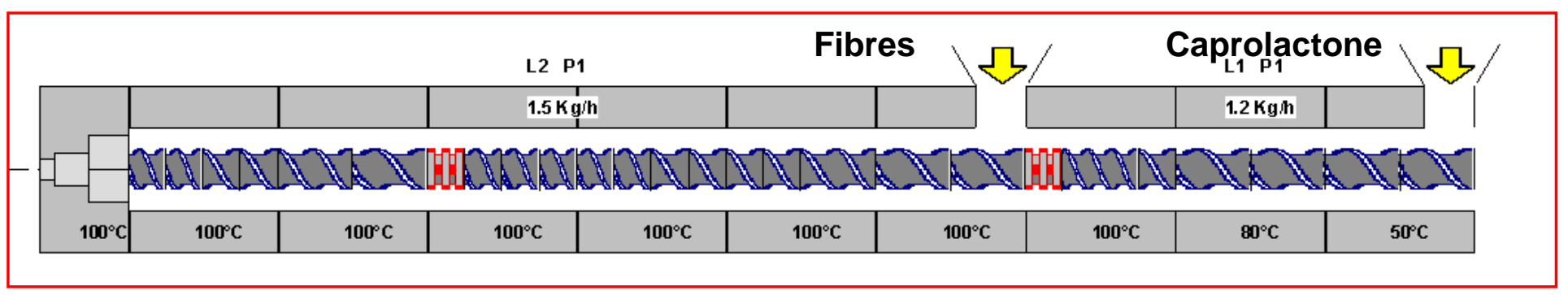

Study of extrusion conditions (at constant humidity $50 \%$ and temperature $100^{\circ} \mathrm{C}$ )

- Influence of screw speed: 100 - 200 - 300 - 400 (rpm)

- Influence of feed rate: $0.85-1.5(\mathrm{~kg} / \mathrm{h})$ 
Characterization - Extruded hemp fibres

Fibres morphology (L/W)

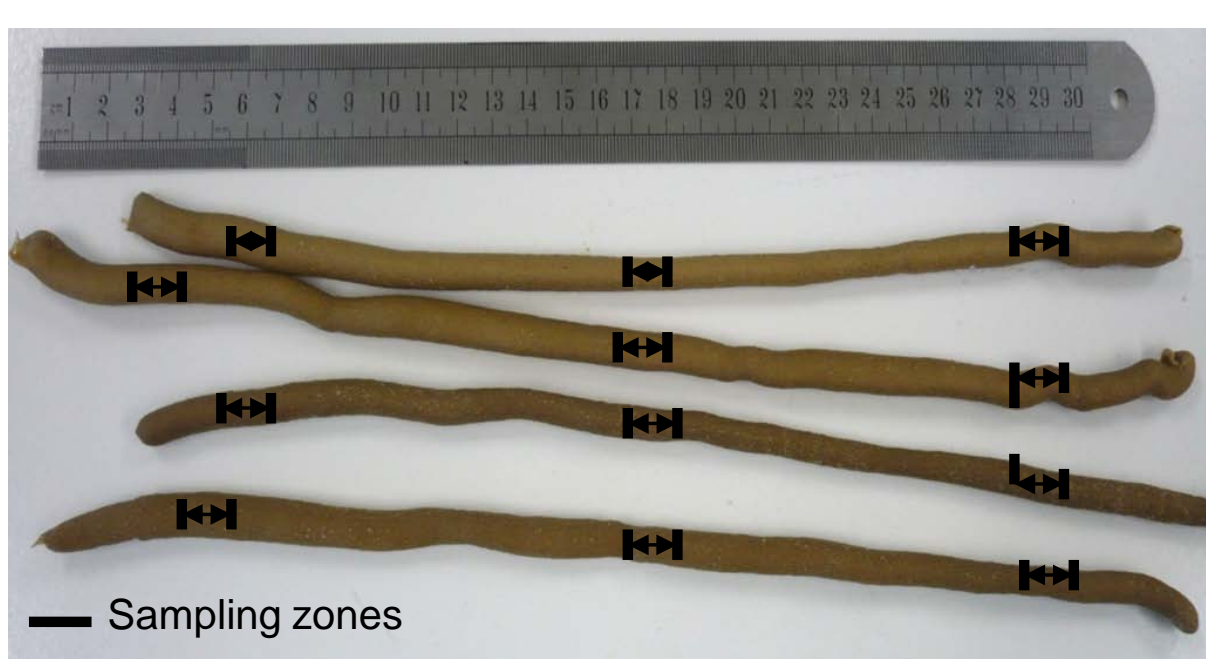

Optical Image Analysis

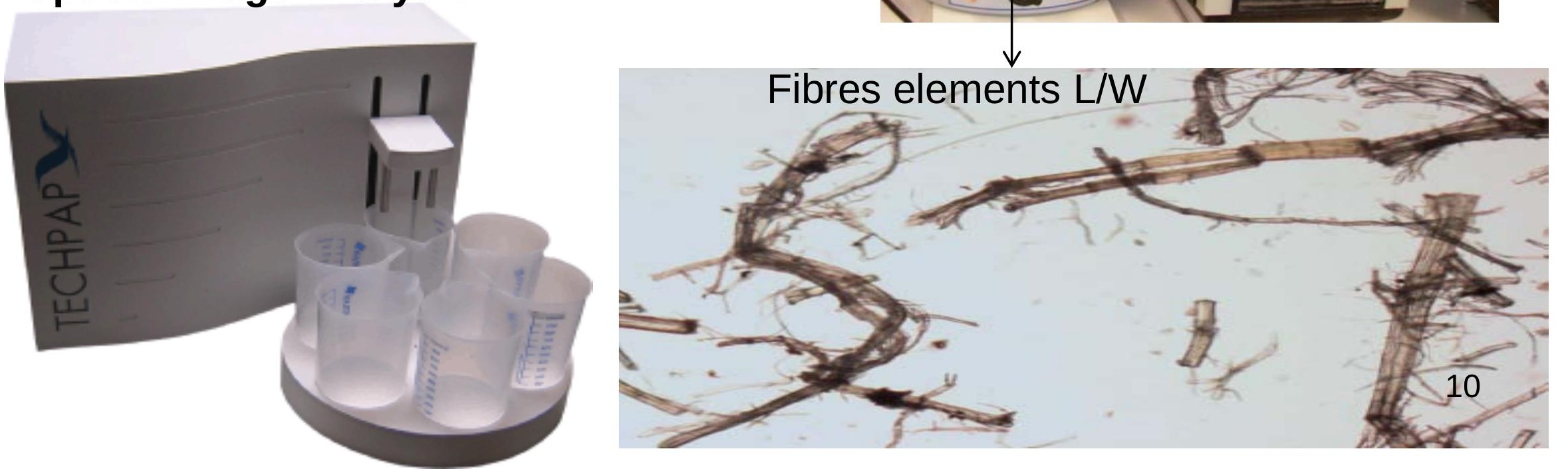




\section{Results: effects of extrusion conditions}

o Computation of the total SME and SME received by fibers

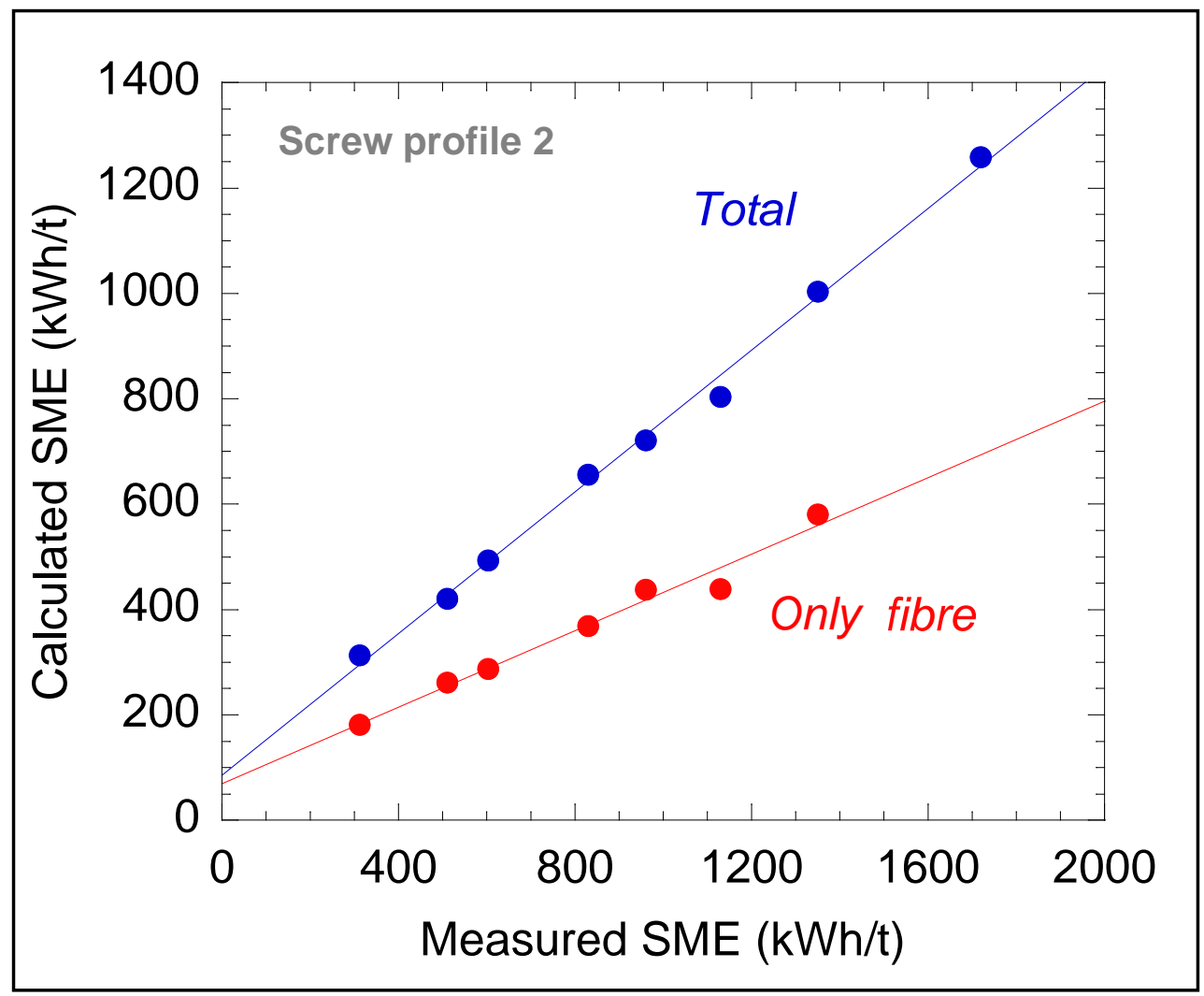

$\square$ Good fitting of experimental and simulated SME for total energy

$\square$ Slight underestimation of SME calculated by LUDOVIC ${ }^{\odot}$ 


\section{Results: conditions of twin-screw extrusion}

o Effects of screw speed and feed rate (profile 2)

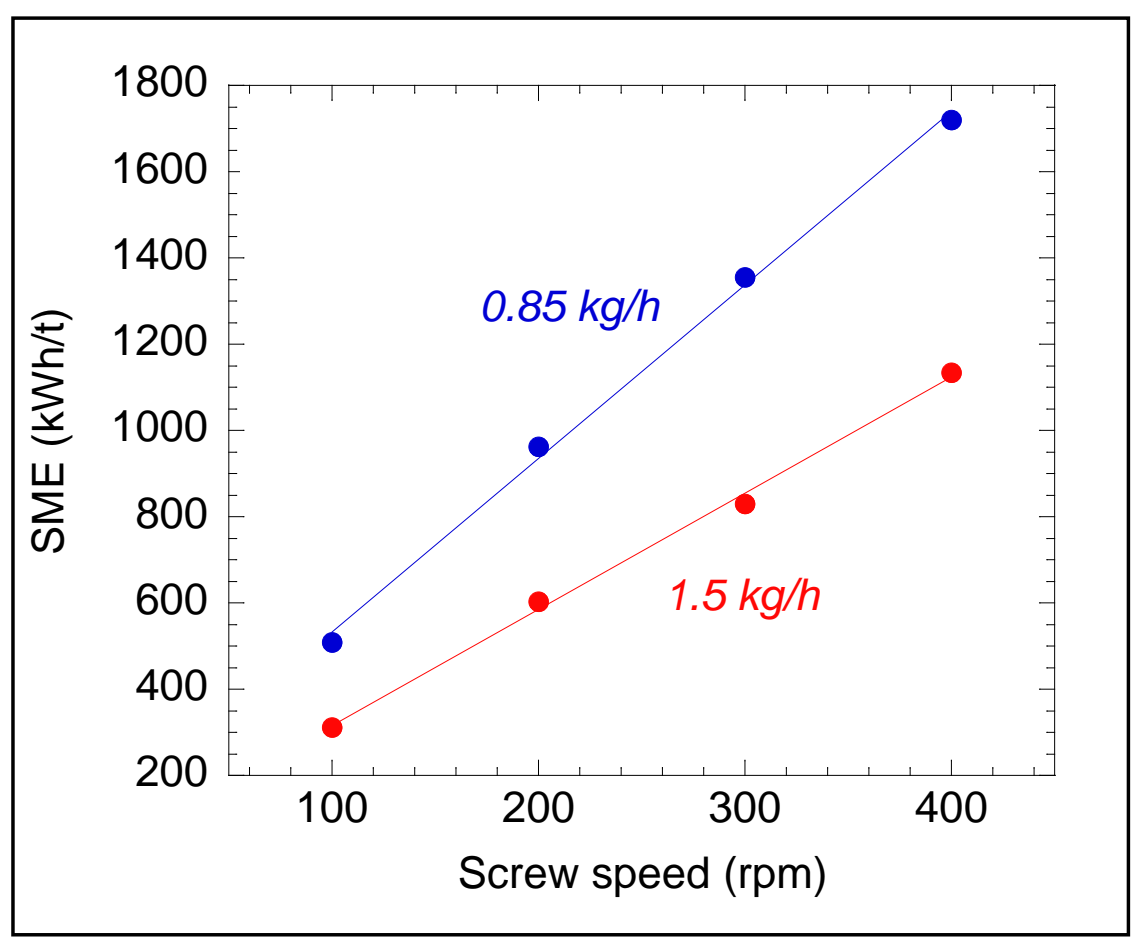

$\square$ SME $\pi$ if screw speed $\pi$

$\square$ SME $\searrow$ if feed rate $\pi$ 


\section{Results: characterization of fibres}

o Effects of formulation (profile 1, $250 \mathrm{rpm}, 0.85 \mathrm{~kg} / \mathrm{h}$ )

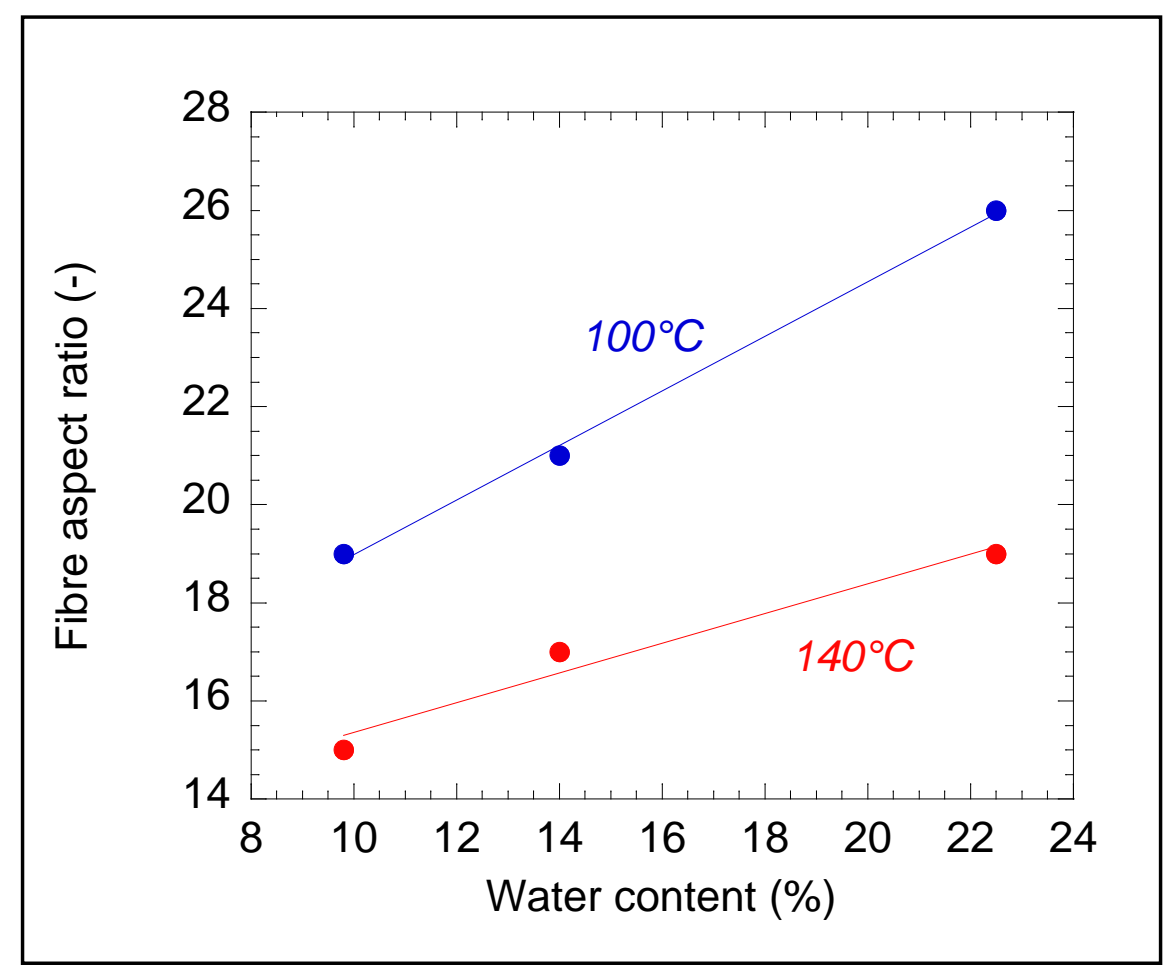

$\square$ Fibres water content $\pi \rightarrow$ L/W $\pi$

$\square$ Extrusion temperature $\lambda \rightarrow$ L/W 


\section{Results: characterization of fibres}

- Effects of extrusion conditions (profile 2)

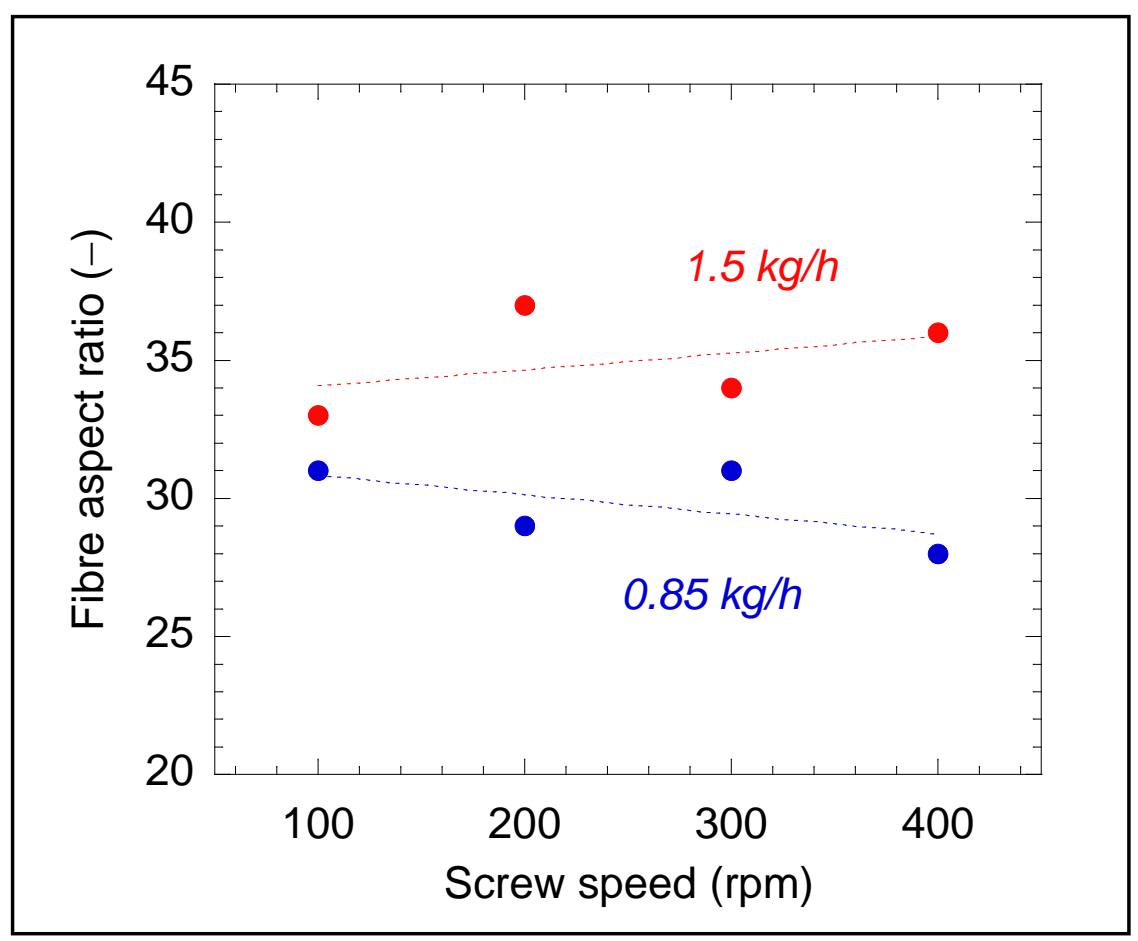

$\square$ Screw speed $\pi \rightarrow L / W \approx$

$\square$ Feed rate $\pi \rightarrow$ L/W $\pi$ 


\section{Results: influence of extrusion conditions}

o Effects of SME
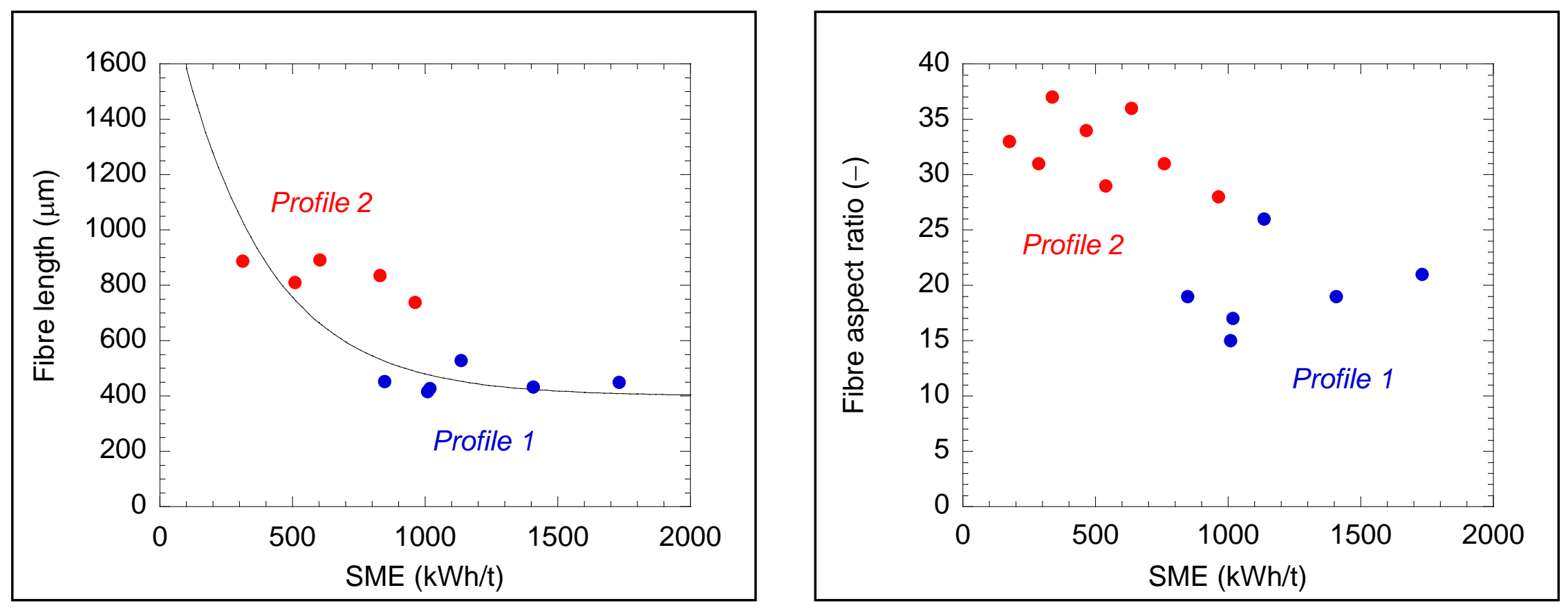

$\square \quad \mathrm{L}=\mathrm{L}_{\infty}+\left(\mathrm{L}_{0}-\mathrm{L}_{\infty}\right) \exp (-\mathrm{K} . \mathrm{SME})$

$\mathrm{L}_{0}=2000 \mathrm{~mm}, \mathrm{~L}_{\infty}=400 \mathrm{~mm}$ and $\mathrm{K}=0.003(\mathrm{kWh} / \mathrm{t})^{-1}$

$\square \quad \mathrm{L}$ and L/W ע with SME

$\square \quad L$ and $L / W \quad \searrow$ with profile 1 


\section{Results: mechanical properties}

o Effects of formulation (profile 1, $250 \mathrm{rpm}, 0.85 \mathrm{~kg} / \mathrm{h}$ )
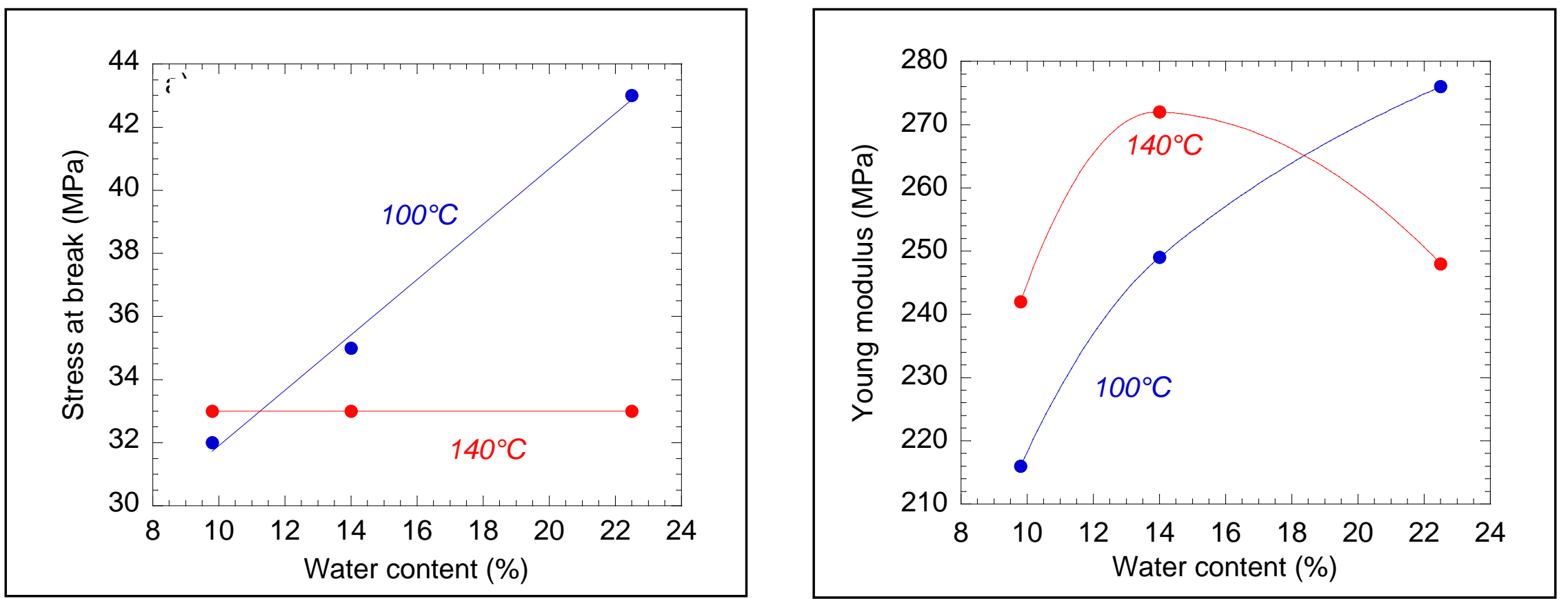

$\square$ Water content $\lambda \rightarrow$ Stress and Young modulus $\lambda$ at $100^{\circ} \mathrm{C}$ $\square$ Different behavior at $140^{\circ} \mathrm{C}$ 


\section{Results: mechanical properties}

o Effects of fiber aspect ratio (profile 1, $250 \mathrm{rpm}, 0.85 \mathrm{~kg} / \mathrm{h}$ )
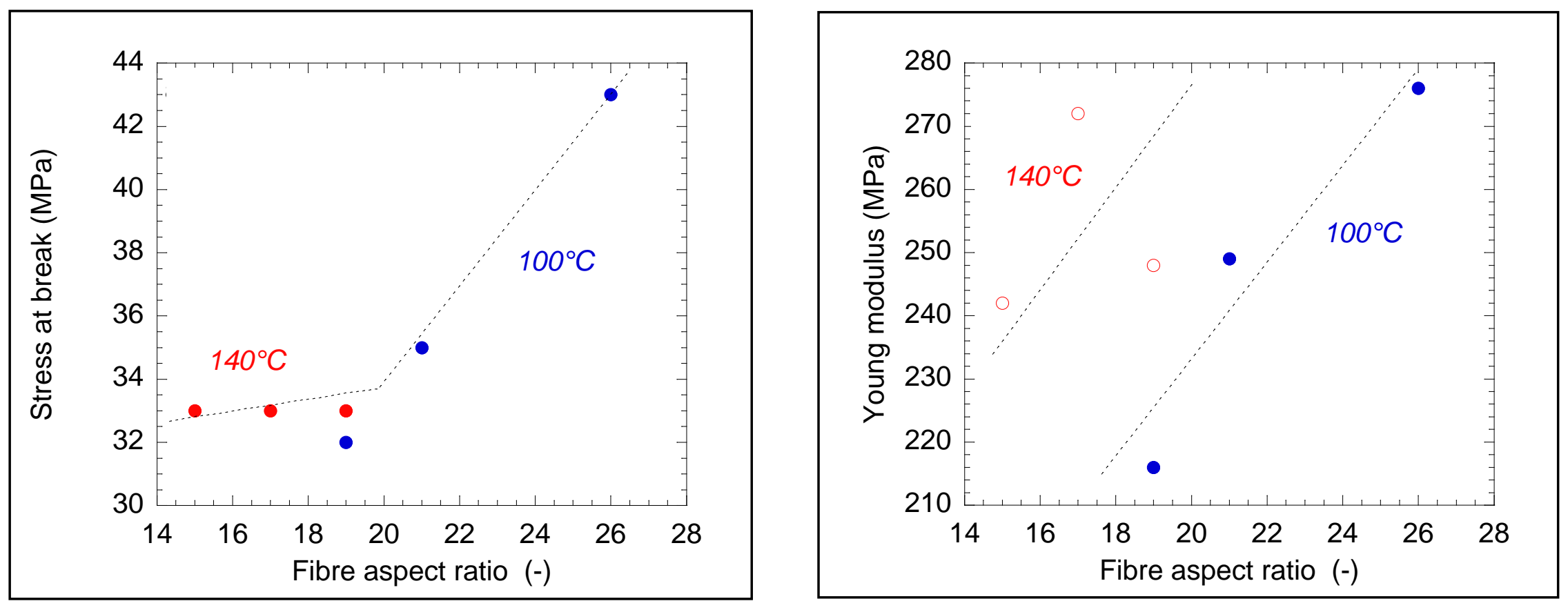

$\square$ Aspect ratio $\lambda \rightarrow$ Stress and Young modulus $\pi$

$\square$ Influence of temperature 


\section{Results: mechanical properties}

- Effects of extrusion conditions (profile 2)
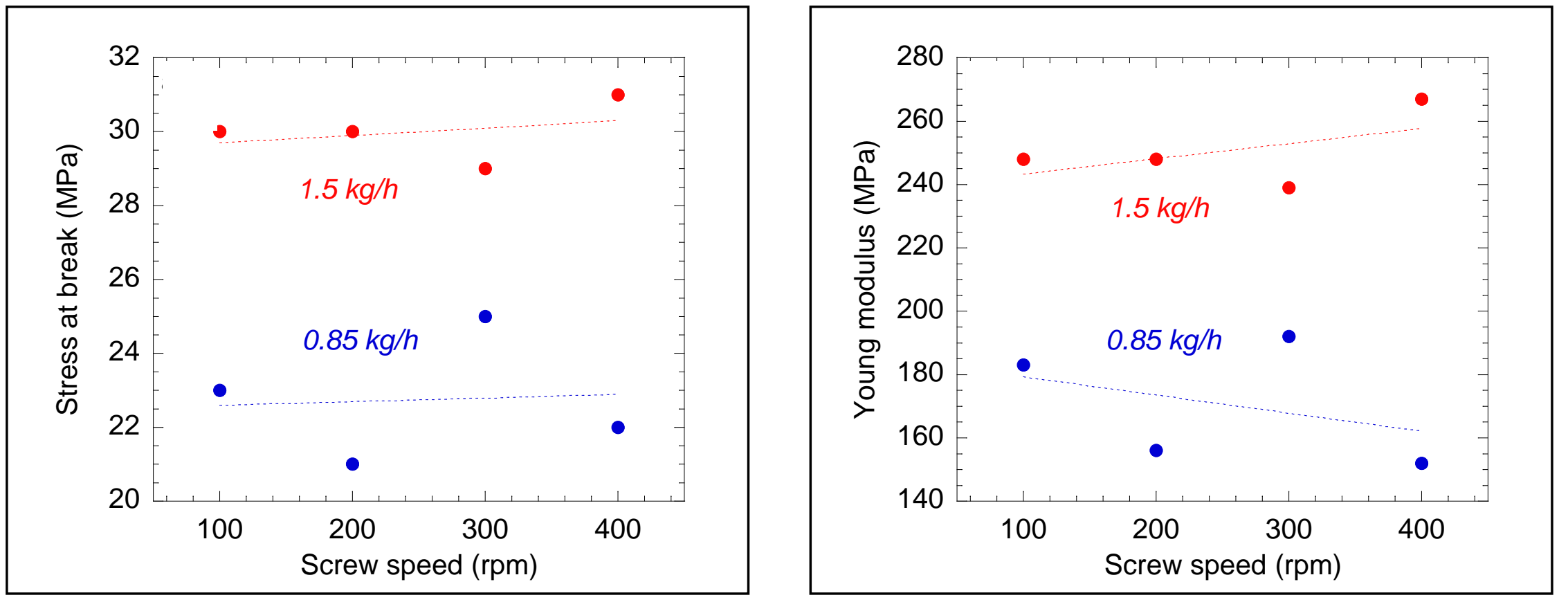

$\square \quad$ Low or no effect of screw speed

$\square$ Feed rate $\pi \rightarrow$ Stress and Young modulus $\pi$ 


\section{Results: mechanical properties}

- Effects of fibre aspect ratio (profile 2)
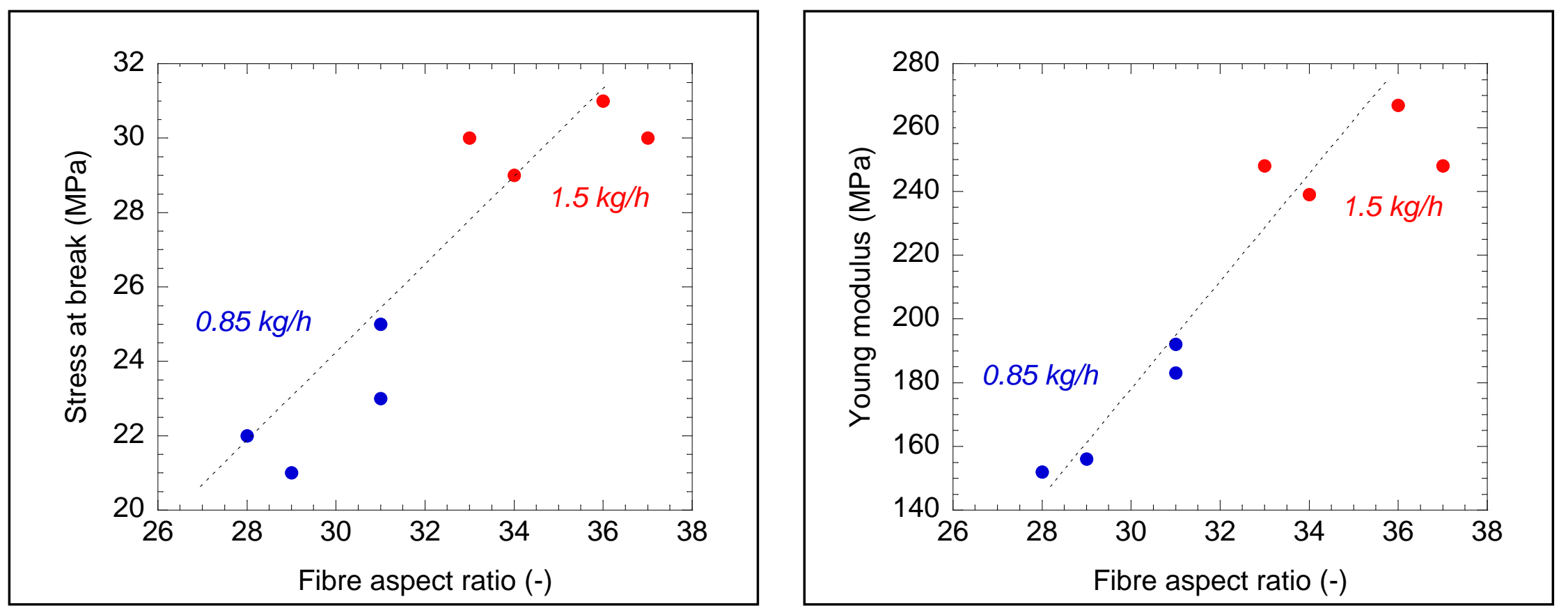

$\square \quad$ Mechanical properties (stress at break and Young modulus) are affected by L/W 


\section{Results: properties - morphology correlation}

- Effects of fibre aspect ratio (profiles 1 and 2)
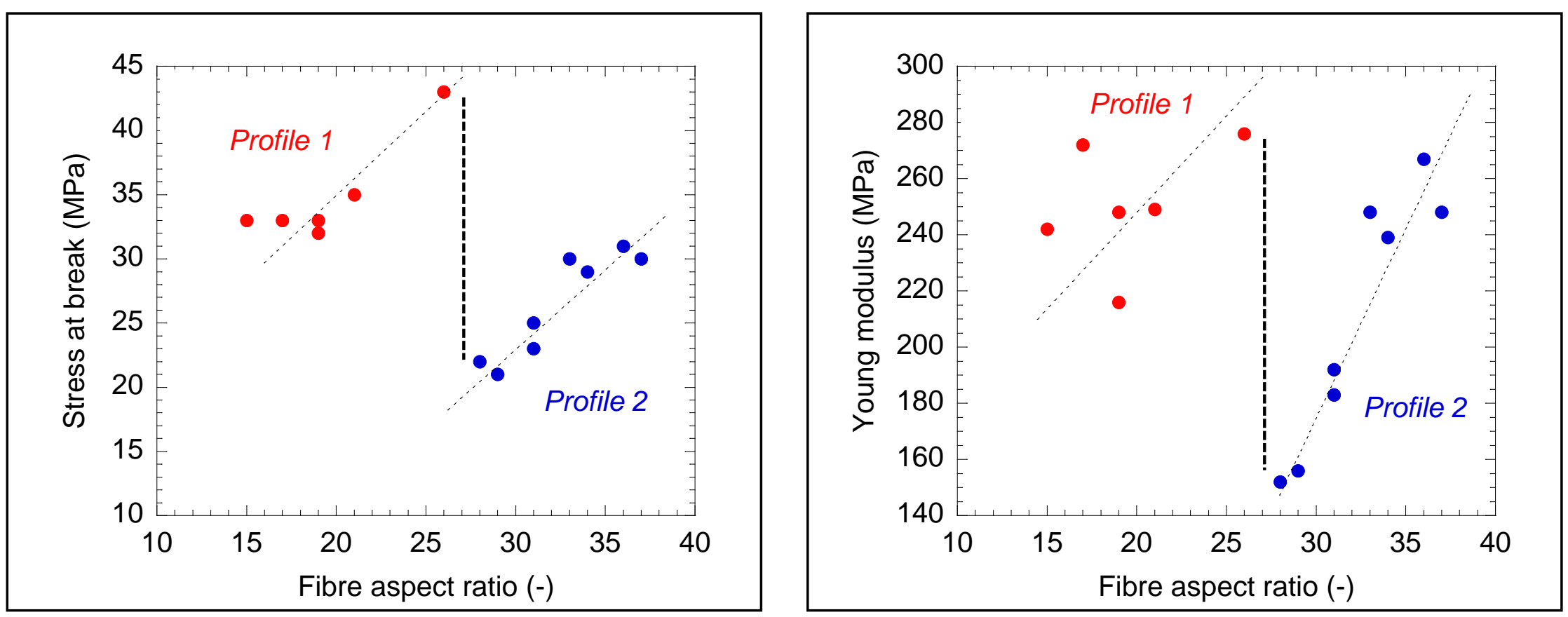

$\square \quad$ No identical properties between screw profiles $1 \& 2$

$\square$ Problem: at identical L/W ratio $\rightarrow \neq$ material properties 


\section{Is it possible to control the defibring in order to enhance the mechanical properties of composites?}

$\square$ Yes, partial control of the defibring can be done and useful for mechanical properties enhancement

- Fiber defibring depends on extrusion conditions (rotation speed and feed rate) through SME

- To favour $\pi$ L/W: twin-screw extrusion at high feed rate (low SME) as for glass fiber (limit breakages)

$\square$ No simple relation between L/W and mechanical properties: other influences (size and fibre adhesion...) 


\section{Contacts:}

Physical and chemical transformations of lignocelluloses (fibres and composites): http://www.lille.inra.fr

johnny.Beaugrand@reims.inra.fr francoise.berzin@univ-reims.fr

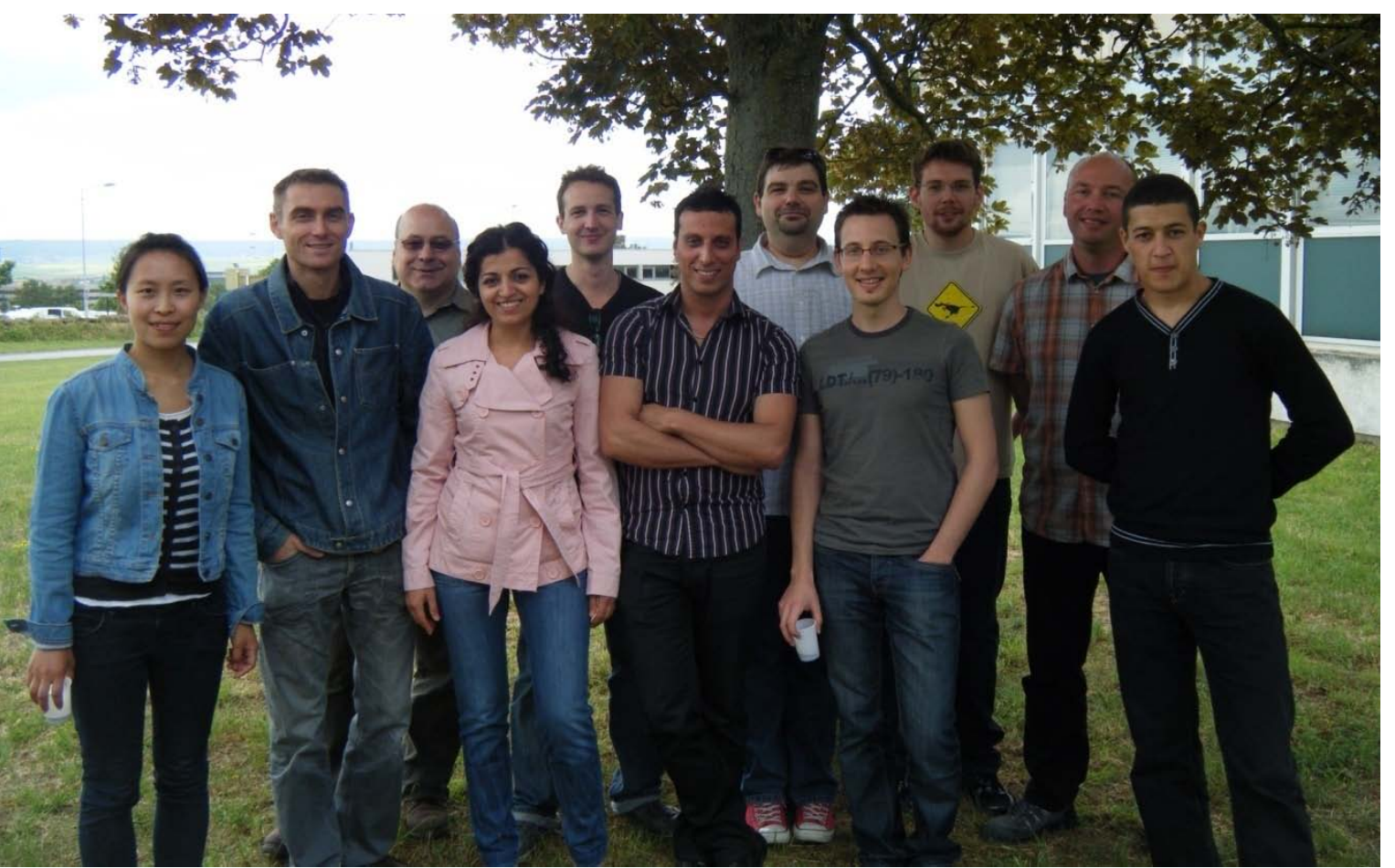

Financial support:

MATOREN program
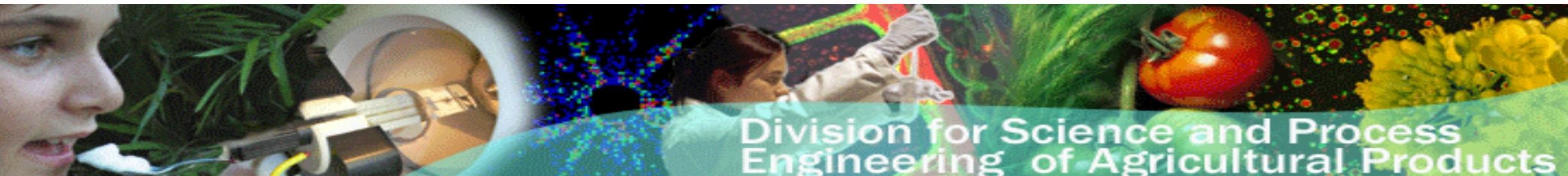